\title{
PERAN GURU DALAM MENGEMBANGKAN KETERAMPILAN \\ KOMUNIKASI (COMMUNICATION) SISWA KELAS V SEKOLAH DASAR NEGERI TERATAI \\ Hendra Budiono ${ }^{1}$, Muhammad Abdurrohim ${ }^{2}$ \\ 1,2Program Studi Guru Sekolah Dasar, Universitas Jambi \\ e-mail: hendra.budiono@ unja.ac.id 1, rohiimjr@gmail.com ${ }^{2}$
}

Received : 12 June, $2020 \quad$ Revised : 14 June, $2020 \quad$ Accpeted : 16 June, 2020

\begin{abstract}
ABSTRAK
Penelitian ini bertujuan untuk mendeskripsikan peran guru dalam mengembangkan keterampilan komunikasi siswa kelas VA SD Negeri 34/I Teratai. Data penelitian diperoleh melalui proses triangulasi yang terdiri atas analisis data observasi, wawancara dan dokumentasi aktivitas pembelajaran yang merujuk pada topik penelitian. Berdasarkan data tersebut, peneliti menemukan peran penting guru dalam mengembangkan keterampilan komunikasi siswa yaitu: 1) Guru sebagai model atau contoh; 2) Guru sebagai motivator; 3) Guru sebagai pembimbing; 4) Guru sebagai fasilitator; 5) Guru sebagai pendidik.

Kata Kunci: Peran Guru, Siswa, Keterampilan Komunikasi

ABSTRACT

This study aims to describe the role of the teacher in developing communication skills for VA grade students of SD Negeri 34 / I Lotus. The research data was obtained through a triangulation process consisting of observational data analysis, interviews and documentation of learning activities that refer to the research topic. Based on these data, the researcher found the teacher's important role in developing students' communication skills, namely: 1) The teacher as a model or example; 2) The teacher as a motivator; 3) The teacher as a guide; 4) The teacher as a facilitator; 5) Teachers as educators.
\end{abstract}

Keywords: Teacher Role, Students, Communication Skills 


\section{PENDAHULUAN}

Sebagaimana dijelaskan dalam Permendikbud No. 20 Tahun 2016 Tentang Standar Kompetensi Lulusan Pendidikan Dasar dan Menengah bahwa "Setiap lulusan satuan pendidikan dasar dan menengah memiliki kompetensi pada tiga dimensi yaitu sikap, pengetahuan, dan keterampilan. Adapun dimensi keterampilan dalam hal ini khususnya pada jenjang pendidikan dasar menyangkut hal sebagai berikut: 1) kreatif; 2) produktif; 3) kritis; 4) mandiri; 5) kolaboratif; dan 6)komunikatif'. Keterampilan yang dimaksud pada abad 21 ini adalah 4C yang merupakan singkatan dari Critical Thinking (Berpikir kritis), Creativity (Kreativitas), Collaboration (Kerja sama) dan Communication (Komunikasi).

Khalik dalam Wilhalminah, A, dkk (2017: 42) menjelaskan bahwa komunikasi akan berlangsung baik apabila terdapat keseragaman makna antara pemberi dan penerima informasi. Senada dengan pendapat tersebut, Musfiqon dalam Astuti dan Leonard (20:103) juga menjelaskan bahwa komunikasi merupakan kegiatan yang selalu dilakukan setiap individu untuk menyalurkan ide atau gagasan dari satu pihak ke pihak lain baik antar manusia maupun dengan alam sekitar".

Komunikasi dapat diartikan sebagai pemberitahuan pembicaraan, percakapan, pertukaran pikiran atau hubungan antara satu dengan yang lainnya. US-based Partnership for 21st Century Skills (P21) dalam Zubaidah (2016: 4) mengutarakan bahwa keterampilan komunikasi mencakup beberapa aspek yakni: Kemampuan dalam menyampaikan opini dan pemikiran dengan jelas dan persuasif, menyampaikan perintah dengan jelas, dan dapat memotivasi seseorang melalui apa yang ia sampaikan.

Kunci keberhasilan siswa dalam menguasai keterampilan komunikasi berada ditangan guru. Peran guru sangat penting dalam mengembangkan kecerdasan dan keterampilan siswa yang dalam hal ini ialah keterampilan komunikasi, hal tersebut tidak akan berkembang secara optimal tanpa bantuan guru. Menurut Adam dan Deccey dalam Maryono (2017: 83) peran guru dalam proses pembelajaran adalah "1) guru sebagai pengajar; 2) guru sebagai pengelola kelas; 3) guru sebagai mediator dan fasilitator; 4) guru sebagai evaluator". 
Berdasan pembahasan diatas, penelitian ini bertujuan untuk mendeskripsikan peran guru dalam mengembangkan keterampilan komunikasi siswa kelas VA SD Negeri 34/I Teratai.

\section{METODE}

Penelitian ini menggunakan metode kualitatif, yang meneliti dan mendeskripsikan fenomena yang terjadi pada subjek penelitian secara holistik, apa adanya dan pada kondisi yang alamiah. Teknik sampling yang digunakan peneliti adalah Purposive Sampling, yang berarti sampel dipilih dan ditentukan berdasarkan kriteria-kriteria yang telah ditentukan sesuai tujuan penelitian sehingga sampel yang dipilih ialah guru yang telah mampu mengembangkan keterampilan komunikasi dalam pembelajaran.

Peneliti melaksanakan penelitian dengan sampel guru kelas VA SD Negeri 34/I Teratai. Penelitian ini mendeskripsikan peran guru dalam mengembangkan keterampilan komunikasi (Communication) siswa kelas VA SD Negeri 34/I Teratai. Data penelitian diperoleh dari proses observasi, wawancara dan dokumentasi di lapangan sehingga peneliti menggunakan teknis analisis data berupa triangulasi teknik sesuai tahap pemerolehan data. Sebagaimana yang dikemukakan oleh Sugiyono dalam Syahrial dkk (2019: 236) bahwa 'triangulasi merupakan penggabungan berbagai macam teknik pengumpulan data dan sumber data yang tersedia".

Penelitian ini menggunakan teknik analisis data lapangan model Miles dan Huberman. Sugiyono dalam Wibowo dan Maqfirotun (2016: 66-67) menjelaskan bahwa "teknik analisis data Miles dan Huberman dilakukan secara interaktif dan berlangsung dengan terus menerus hingga datanya jenuh". Teknik Miles dan Huberman dilakukan dengan tiga tahap, yaitu:

\section{Reduksi Data}

Data yang diperoleh dari lapangan jumlahnya cukup banyak sehingga harus dicatat dengan teliti dan rinci. Semakin lama peneliti dilapangan maka semakin banyak pula data yang peneliti peroleh untuk dianalisis dengan reduksi data. 
2. Penyajian Data

Penyajian data dapat dilakukan dalam bentuk uraian singkat, bagan, dan sejenisnya. Pada penelitian ini, penyajian data dilakukan dalam bentuk uraian singkat analisis hasil observasi, wawancara dan dokumentasi.

3. Penarikan Kesimpulan

Penarikan kesimpulan diawal yang dikemukakan masih bersifat sementara dan akan berubah apabila terdapat bukti-bukti yang kuat dalam pengumpulan data berikutnya. Akan tetapi, apabila kesimpulan yang dikemukakan pada tahap awal didukung oleh bukti yang kuat dan valid serta konsisten daat peneliti kembali kelapangan untuk mengumpulkan data, maka kesimpulan yang dikemukakan merupakan kesimpulan yang kuat.

\section{PEMBAHASAN}

Pengambilan data penelitian dilakukan melalui proses observasi, wawancara dan analisis dokumentasi untuk menganalisis peran guru dalam mengembangkan keterampilan komunikasi siswa di kelas VA SD Negeri 34/I Teratai. Temuan data penelitian merujuk pada analisis indikator keterampilan komunikasi pada proses pembelajaran, upaya yang dilakukan guru serta peran guru dalam mengembangkan keterampilan komunikasi siswa di kelas VA SD Negeri 34/I Teratai yang dijabarkan sebagai berikut:

\section{1) Proses Pembelajaran Di Kelas VA Sdn 34/I Teratai}

Berdasarkan pengamatan yang telah dilakukan pada saat proses pembelajaran, terlihat bahwa kondisi siswa yang diajar tidak jauh berbeda dengan kondisi pada umumnya. Karakteristik siswa yang berbeda menjadikan faktor yang menentukan dalam pengkondisian kelas. Para siswa berani dan mampu menyampaikan pendapat mereka mengenai persoalan yang ada dengan baik. Siswa juga terlihat aktif dan antusias dalam menjawab pertanyaan yang diajukan oleh guru. Banyak siswa yang mampu menyampaikan informasi dengan menggunakan bahasa yang baik, artikulasinya jelas dan mudah di pahami oleh teman-temannya. Namun demikian, siswa masih memerlukan bimbingan dan dorongan dari guru agar keterampilan komunikasi siswa lebih optimal. 


\section{2) Upaya Guru dalam mengembangkan Keterampilan Komunikasi Siswa}

Kelas VA SDN 34/I Teratai.

Berdasarkan temuan di lapangan, terlihat jelas bahwa guru berusaha semaksimal mungkin untuk mengembangkan keterampilan komunikasi siswa. Salah satu upaya yang dilakukan oleh guru adalah dengan menerapkan model pembelajaran berbasis proyek. Model pembelajaran berbasis proyek menurut Buck Institute for Education (BIE) dalam Trianto (2014:41) merupakan "pembelajaran yang melibatkan siswa dalam kegiatan pembelajaran berupa pemecahan masalah dan memberikan kesempatan bagi siswa untuk menampilkan gagasannya serta dapat meningkatkan hasil belajar dan keterampilan siswa". Model pembelajaran berbasis proyek memiliki beberapa karakteristik salah satunya ialah "siswa didorong untuk berfikir kritis, memecahkan masalah, berkolaborasi, serta mencoba berbagai macam bentuk komunikasi".

Dengan menerapkan model pembelajaran tersebut siswa terlihat lebih aktif dan antusias dalam proses pembelajaran. Siswa diberikan sebuah proyek oleh guru untuk diselesaikan bersama teman dalam kelompoknya. Dengan begitu, komunikasi menjadi hal yang sangat penting karena didalam menyelesaikan proyek tersebut tentunya dibutuhkan informasi-informasi yang benar dan terpercaya sehingga penyampaian informasi harus jelas agar tidak terjadi salah komunikasi dalam penyelesaian proyek. Selain itu, siswa juga harus aktif bertanya agar banyak mendapatkan informasi-informasi. Kemudian siswa juga harus menjadi pendengar yang baik, agar informasi yang ia dengar dapat di implementasikan dengan benar. Hal tersebut secara terus menerus di latih oleh guru agar siswa terbiasa untuk berkomunikasi sehingga keterampilan komunikasi siswa semakin berkembang dengan optimal.

\section{3) Peran guru dalam mengembangkan keterampilan komunikasi siswa}

Berdasarkan pengamatan yang peneliti lakukan, terlihat bahwa dalam mengembangkan keterampilan komunikasi siswa guru berperan sebagai fasilitator melalui pembiasaan-pembiasaan ataupun memberikan kesempatan kepada siswa untuk berbicara, baik untuk bertanya maupun menyampaikan pendapat. Guru juga memberikan contoh secara langsung bagaimana menyampaikan informasi dengan baik, jelas dan mudah dipahami. Selain itu guru juga berperan sebagai motivator bagi siswa, guru memberikan perhatian 
lebih kepada siswa yang cenderung pasif di kelas. Guru selalu memberikan motivasi kepada siswa tersebut agar siswa berani untuk menyampaikan pendapat. Terlepas dari apa yang disampaikan oleh siswa tepat atau tidak guru juga selalu mengajak siswa lain untuk memberikan apresiasi kepada siswa yang telah berani mengemukakan pendapatnya. Hal tersebut dilakukan guru untuk meningkatkan rasa percaya diri siswa, sehingga siswa berani dan terbiasa untuk berbicara.

Dalam proses pembelajaran, komunikasi merupakan hal yang sangat penting bagi siswa, karena pada pembelajaran kurikulum 2013 siswa dituntut untuk aktif dalam proses pembelajaran. Oleh karena itu, peran guru adalah mendorong, membimbing, dan mengarahkan agar siswa mampu menghasilkan cara-cara atau langkah yang dihasilkan dengan cara mereka sendiri. Tugas seorang guru hanyalah membimbing dan mengarahkan keterampilan komunikasi siswa secara maksimal sedangkan siswa itu sendiri yang mengolah keterampilan komunikasi tersebut.

Berdasarkan temuan-temuan di atas merujuk pada pencapaian keterampilan siswa dalam berkomunikasi. Keterampilan komunikasi memiliki empat indikator pencapaian dalam proses pembelajaran, yaitu: 1) Mampu mengeluarkan ide dan pemikiran dengan efektif; 2) Mampu mendengarkan dengan efektif; 3) Mampu menyampaikan informasi dengan baik; 4) Menggunakan bahasa yang baik dan efektif. Sebagaimana yang dikemukakan oleh Khalik dalam Wihalminah dkk (2017: 42) bahwa komunikasi akan berjalan dengan baik apabila pemberi informasi dan penerima informasi memberikan makna yang sama terhadap tanda-tanda yang digunakan sebagai pesan dalam komunikasi atau dalam kata lain keduanya memiliki keselarasan sehingga tidak terjadi kesalahan dalam berkomunikasi.

Guru dalam mengembangkan keterampilan komunikasi siswa tersebut dengan menggunakan beberapa cara, yaitu: 1) Guru merancang pembelajaran berupa pemilihan metode, pendekatan, strategi dan model pembelajaran yang dapat meningkatkan interaksi baik antar guru dan siswa maupun siswa dengan siswa dengan cara membuat kelompok-kelompok kecil dalam mengerjakan persoalan. Dalam hal ini guru menerapkan model pembelajaran berbasis proyek guna mendukung siswa untuk mengembangkan keterampilan komunikasinya; 2) Guru memberikan contoh secara langsung bagaimana 
menyampaikan informasi dengan baik, terlihat dari bahasa yang digunakan oleh guru dalam berkomunikasi dengan siswa guru menggunakan bahasa yang jelas dan mudah di pahami oleh siswa; 3) Guru banyak memberikan kesempatan kepada siswa untuk aktif bertanya dan menyampaikan pendapat, cara tersebut dilakukan oleh guru agar siswa terbiasa untuk berbicara dan berani menyampaikan pendapat. Hal tersebut dilakukan oleh guru kepada semua siswa tidak hanya beberapa siswa saja, sehingga semua siswa mendapatkan kesempatan untuk mengembangkan keterampilan komunikasi mereka; 4) Guru memberikan perhatian lebih kepada siswa yang cenderung pasif dalam proses pembelajaran, guru terlihat seringkali memberikan motivasi kepada siswa yang cenderung pasif tersebut dan banyak memberikan kesempatan kepada siswa tersebut untuk berani berbicara dan menyampaikan pendapat; 5) Guru memberikan penghargaan kepada siswa yang berani bertanya dan menyampaikan pendapat, terlepas dari apa yang disampaikan sudah tepat atau tidak guru tetap memberikan apresiasi dan mengajak temanteman siswa yang lain untuk memberikan tepuk tangan. Hal tersebut dilakukan oleh guru agar siswa semakin percaya diri untuk berani berkomunikasi sehingga dengan proses bimbingan dan arahan yang terus dilakukan guru, keterampilan komunikasi siswa dapat berkembang lebih optimal.

Sejalan dengan hal tersebut, Curtis dan Bidwell dalam Zein (2016: 279) menjelaskan bahwa peranan guru dalam proses pembelajaran adalah sebagai pengorganisasi lingkungan belajar sekaligus sebagai fasilitator belajar, guru juga berperan sebagai pembimbing, dalam arti kata guru sebagai penunjuk jalan kemana arah dan tujuan yang akan dicapai, selain itu guru juga sebagai model atau contoh bagi siswanya. Guru harus mampu menjadi tauladan bagi siswanya, yang dalam hal ini berkaitan dengan keterampilan komunikasi, guru mampu memberikan contoh berkomunikasi yang baik, menyampaikan informasi dengan jelas dan tepat. Oleh karena itu, peran seorang guru dalam proses pembelajaran dikelas sangatlah penting, khususnya dalam mengembangkan keterampilan komunikasi siswa. Maka dalam mengembangkan keterampilan komunikasi guru harus mampu berperan sebagai model atau contoh, sebagai motivator, prmbimbing, fasilitator dan pendidik. 


\section{KESIMPULAN}

Deskripsi temuan-temuan penelitian menunjukkan indikator keterampilan komunikasi, meliputi: 1) Mampu mengeluarkan ide dan pemikiran dengan efektif; 2) Mampu mendengarkan dengan efektif; 3) Mampu menyampaikan informasi dengan baik; 4) Menggunakan bahasa yang baik dan efektif. Guru dalam mengembangkan keterampilan komunikasi siswa tersebut dengan menggunakan beberapa cara, yaitu: 1) Guru merancang pembelajaran berupa pemilihan metode, pendekatan, strategi dan model pembelajaran yang dapat meningkatkan interaksi baik antar guru dan siswa maupun siswa dengan siswa dengan cara membuat kelompok-kelompok kecil dalam mengerjakan persoalan. 2) Guru memberikan contoh secara langsung bagaimana menyampaikan informasi dengan baik; 3) Guru banyak memberikan kesempatan kepada siswa untuk aktif bertanya dan menyampaikan pendapat; 4) Guru memberikan perhatian lebih kepada siswa yang cenderung pasif dalam proses pembelajaran; 5) Guru memberikan penghargaan kepada siswa yang berani bertanya dan menyampaikan pendapat,

Berdasarakan deskripsi tersebut, peneliti menemukan peran penting guru dalam mengembangkan keterampilan komunikasi siswa yaitu: 1) Guru sebagai model atau contoh; 2) Guru sebagai motivator; 3) Guru sebagai pembimbing; 4) Guru sebagai fasilitator; 5) Guru sebagai pendidik.

\section{DAFTAR PUSTAKA}

Hariandi, A., \& Irawan, Y. (2016). Peran Guru dalam Penanaman Nilai Karakter Religius di Lingkungan Sekolah pada Siswa Sekolah Dasar. Jurnal Gentala Pendidikan Dasar, 1(1), 176-189.

Kemendikbud. (2016). Permendikbud No. 20 Tentang Standar Kompetensi Lulusan Pendidikan Dasar dan Menengah. Jakarta: Kementerian Pendidikan dan Kebudayaan.

Maryono, M. (2017). Peran Guru Dalam Menerapkan Pembelajaran Tematik Di Sekolah Dasar. Jurnal Gentala Pendidikan Dasar, 2(1), 72-89.

Prastowo, A. (2012). Metode Penelitian Kualitatif dalam Prespektif Rancangan Penelitian. Jogjakarta: AR-RUZZ MEDIA

Suwardi, I., \& Farnisa, R. (2018). Hubungan Peran Guru Dalam Proses Pembelajaran Terhadap Prestasi Belajar Siswa. Jurnal Gentala Pendidikan Dasar, 3(2), 181-202. 
Syahrial, S., Kurniawan, A. R., Alirmansyah, A., \& Alazi, A. (2019). Strategi Guru dalam Menumbuhkan Nilai Kebersamaan pada Pendidikan Multikultural di Sekolah Dasar. Jurnal Gentala Pendidikan Dasar,4(2), 232-244.

Trianto. (2014). Mendesain Model Pembelajaran Inovatif, Progresif dan Kontekstual. Jakarta: Kencana

Wibowo, I. S., \& Maqfirotun, S. (2016). Peran Guru dalam Membentuk Tanggung Jawab Siswa Kelas V Sekolah Dasar. Jurnal Gentala Pendidikan Dasar, 1(1), 61-72.

Wilhalminah, A, dkk. (2017). Pengaruh Keterampilan Komunikasi Terhadap Perkembangan Moral Siswa Pada Mata Pelajaran Biologi Kelas XI IPA SMA Muhammadiyah Limbung. Jurnal Biotek. 5(2): 37-52.

Zein, M. (2016). Peran Guru Dalam Pengembangan Pembelajaran. Jurnal Pendidikan Dasar Islam. V(2): 274-285

Zubaidah, S. (2016). Keterampilan Abad Ke- 21: Keterampilan Yang Diajarkan Melalui Pembelajaran. Seminar Nasional Pendidikan: 1-17 